\title{
Editors’ Notes
}

\section{ERRATUM}

In the March 2009 issue of the Journal, in her article, "Time Spent in Home Production in the Twentieth-Century United States: New Estimates from Old Data," Valerie A. Ramey inadvertently omitted the complete reference to one of the key data sets she used. That data set, The American Heritage Time Use Study, was created at the Centre for Time Use Research, United Kingdom, by Kimberly Fisher, Muriel Egerton, and Jonathan Gershuny, with Nuno Torres and Andreas Pollmann, and contributions from Anne H. Gauthier and John Robinson. The data set is available at http://www.timeuse.org.

\section{ECONOMIC HISTORY ASSOCIATION MEETINGS}

The editors and the Association thank those who were program committee members, chairs, discussants, dissertation conveners, local arrangements committee members, and the meeting coordinator.

Jeremy Atack, Vanderbilt University Martha Bailey, University of Michigan Steve Berry, Yale University

Sabrina Boschetti, California Institute of Technology

Stephen Broadberry, University of Warwick

Ben Chabot, University of Michigan Latika Chaudhary, Stanford University

Peter Coclanis, University of North Carolina, Chapel Hill

William Collins, Vanderbilt University

Lee Craig, North Carolina State University

William Darity, Duke University

Tracy Dennison, California Institute of Technology

Jari Eloranta, Appalachian State

University

James Fenske, Yale University

Alexander Field, Santa Clara University

Price Fishback, University of Arizona

Claudia Goldin, Harvard University

Richard Grossman, Wesleyan University

Timothy Guinnane, Yale University

Michael R. Haines, Colgate University

Hal Hansen, Harvard University

Philip Hoffman, California Institute of

Technology
Paul M. Hohenberg, Rensselaer

Polytechnic Institute

Jane Humphries, Oxford University

Joseph Inikori, University of Rochester

Brooks Kaiser, Gettysburg College

B. Zorina Khan, Bowdoin College

Naomi Lamoreaux, University of

California, Los Angeles

Pierre Landry, Yale University

Carol Leonard, Oxford University

Peter Lindert, University of California, Davis

Trevon Logan, Ohio State University

Mary MacKinnon, McGill University

Robert Margo, Boston University

Anne McCants, Massachusetts Institute of Technology

Carolyn Moehling, Rutgers University

Chiaki Moriguchi, Northwestern University

Tom Nicholas, Harvard University

John Nye, George Mason University

Alan L. Olmstead, University of

California, Davis

Kevin O'Rourke, Trinity College

Peter Perdue, Yale University

Leah Platt Boustan, University of

California, Los Angeles

Kenneth Pomeranz, University of

California, Irvine 
Daniel Raff, University of Pennsylvania Paul W. Rhode, University of Arizona Joshua Rosenbloom, University of Kansas

Jean-Laurent Rosenthal, California Institute of Technology

Philip Slavin, Yale University

Richard Steckel, Ohio State University

Koleman Strumpf, University of Kansas Gianini Toniolo, Duke University Francesca Trivellato, Yale University
Werner Troesken, University of Pittsburgh

Nancy Virts, California State University, Northridge

John Wallis, University of Maryland

David Weiman, Barnard College/Columbia University

Brian Wright, University of California, Berkeley

Se Yan, University of California, Los Angeles

\section{ECONOMIC HISTORY ASSOCIATION MEETINGS 11-13 SEPTEMBER 2009}

The sixty-ninth annual meetings of the Economic History Association will be held at the Loews Ventana Canyon Resort Tucson in Tucson, Arizona, 11-13 September 2009. The theme of the meetings is "Human Welfare: Measurement, Analysis, and Interpretation." The papers chosen for presentation follow:

\section{ANTHROPOMETRY AND HEALTH}

John Komlos, University of Munich, "A Quarter Century of Research on the Antebellum Puzzle"

Timothy Cuff, Westminster College, "Biological Welfare Change and Variation in Midto Late-Nineteenth-Century Pennsylvania: Evidence from the Stature of the Pennsylvania National Guard"

Matthias Zehetmeyer, University of Munich, "The Continuing 'Malthusian Squeeze': Nutrition, Mortality, and the Postbellum Puzzle in the United States, 1850 to 1880"

\section{ANTHROPOMETRY AND HEALTH}

Moramay Lopez-Alonso, Rice University, and Lourdes Márquez-Morfín, Escuela Nacional de Antropología e Historia, Mexico, "Measuring Human Welfare in Mexico" Rafael Dobado-Gonzalez, Universidad Complutense, Madrid, "Neither So Low nor So Short! Wages and Heights in Late Colonial Latin America in Comparative Perspective"

Emanuele Felice, University of Bologna, "Income and Human Development: Measuring Regional Disparities in Italy"

\section{DEMOGRAPHY}

Leah Platt Boustan, University of California, Los Angeles and NBER, Ran Abramitzky, Stanford University, and Katherine Eriksson, University of California, Los Angeles, "Measuring Selectivity and Returns in the Age of Mass Migration"

Chiaki Moriguchi, Northwestern University and NBER, "Child Adoption in the United States, 1880-1930: New Evidence from IPUMS"

Francesco Cinnirella, Ifo Institute for Economic Research and CESifo, Bonn, Germany, Sascha O. Becker, University of Stirling, Ifo Institute for Economic Research, CESifo, and IZA, and Ludger Woessmann, University of Munich, CESifo, and IZA, "Education versus Fertility: Evidence from Before the Demographic Transition" 


\section{EDUCATION AND HUMAN CAPITAL}

John Parman, University of California, Davis, "Childhood Health and Human Capital Formation: New Evidence from Genetic Brothers in Arms"

Jeffrey Greenbaum, University of California, Berkeley, "Land Endowments, Child Labor, and the Development of Public Schooling: Evidence from the Early-TwentiethCentury United States"

Dongwoo Yoo, Ohio State University, "Health in the Nineteenth Century through the Lens of Geographically Weighted Regression"

\section{HEALTH}

Kris Inwood, University of Guelph, and Oliver Masakure, University of Guelph, "Inequality and Physical Well-Being Among Coloured and White Men in the Cape Colony Before 1900"

Duol Kim, Korea Development Institute, and Heejin Park, Kyungpook National University, "Measuring Living Standard from the Lowest: Height of the Haengryu Deceased in Colonial Korea"

Eric Chaney, Harvard University, "Change We Can't Believe In: Sheikhs, Sultans, and the Nile"

\section{HEALTH AND LIVING STANDARDS}

Stephen L. Morgan, University of Nottingham, "Adjustment of Age-Related Height Shrinkage in Archival Data for Chinese: A Post Hoc Longitudinal Survey"

Gordon M. Winder, University of Munich, "Taller and Shorter: Stature Within the U.S. Manufacturing Belt, 1850-1880"

Harry Kitsikopoulos, New York University, "Land Productivity and Standards of Living in Medieval England, 1200-1500"

\section{INDUSTRIAL ORGANIZATION AND INSTITUTIONS}

Lisa D. Cook, Michigan State University, “A Green Light for Red Patents? Outsourcing Patent Protection in the Soviet Union and Russia, 1971 to 2007"

Petra Moser, Stanford University and NBER, "Compulsory Licensing: Evidence from the Trading with the Enemy Act"

B. Zorina Khan, Bowdoin College and NBER, "Promoting the Useful Arts: An Empirical Estimation of Technological Innovation Outside the Patent System, 1790-1880"

\section{INEQUALITY AND INCOME}

Julia Mensink, London School of Economics, "The Unexpected Developments of the U.S. Poverty Thresholds: Production, Distribution, and Usage Since 1963"

Sandrine Michel, LASER and IRD, University of Montpellier I, and Delphine Vallade, University of Montpellier III, "The Financing of Social Expenditures and Long-Term Economic Growth: Insights from a Composite Indicator of Historical Human Development, the Case of France from the Middle of the Nineteenth Century to the Present"

Daniel Waldenstrom, Research Institute of Industrial Economics (IFN), Stockholm, Jesper Roine, SITE, Stockholm School of Economics, and Jonas Vlachos, Department of Economics, CEPR and IFN, Stockholm University, "The Long-Run Determinants of Inequality: What Can We Learn from Top Income Data?" 


\section{INSTITUTIONS}

Jessica Hennessey, University of Maryland, "The Adoption of Constitutional Home Rule: A Test of Endogenous Policy Decentralization"

Karen Clay, Carnegie Mellon University, "Dynamic Effects of Legal Origins: Evidence from the American States"

James Fenske, Yale University, "Land Abundance and Economic Institutions: Egba Land and Slavery, 1830-1914"

\section{LABOR}

Joyce Burnette, Wabash College, "The Emergence of Wage Discrimination in U.S. Manufacturing"

Sam Allen, Virginia Military Institute, "State Variation in Workers' Compensation Insurance: A Political Economy of Benefits, 1930-2000"

Christopher Meissner, University of California, Davis, "Riding the Wave of Trade: Explaining the Rise of Labor Regulation in the Golden Age of Globalization"

\section{LIVING STANDARDS}

Hans-Joachim Voth, UPF and CREI, Barcelona, and Jonathan Hersh, University of Chicago, "Sweet Diversity: Colonial Goods and the Rise of European Living Standards After 1492"

Ricardo Fernandes Paixao, University of São Paulo, "Inequality and Growth: A Study on Colonial São Paulo"

Jessica Bean, Cornell University, "Poverty and Women's Work in Interwar London"

\section{PUBLIC FINANCE AND CAPITAL FORMATION}

Latika Chaudhary, Stanford University, "Imperialists, Native Rulers, and Private Companies: New Evidence on the Efficiency of Indian Railways, 1880-1916"

Felipe Tamega Fernandes, London School of Economics, "Taxation and Welfare: The Case of Rubber in the Brazilian Amazon, 1870-1910"

Xavier Duran, Northwestern University, "Was the First Transcontinental Railroad Built Ahead of Demand? Evidence from Entrepreneurial Expectations and an Empirical Entry Decision Model"

\section{PUBLIC POLICY}

Gary Libecap, University of California, Santa Barbara and NBER, and Dean Lueck, University of Arizona, "The Demarcation of Land: Patterns and Economic Effects"

Carolyn Moehling, Rutgers University and NBER, and Melissa Thomasson, Miami University and NBER, "The Political Economy of Saving Mothers and Babies"

Zeynep K. Hansen, Boise State University, and Scott E. Lowe, Boise State University, "Climate Variability and Water Infrastructure: Historical Experience in the Western United States"

\section{PUBLIC POLICY}

William J. Collins, Vanderbilt University and NBER, and Katharine L. Shester, Vanderbilt University, "Slum Clearance and Urban Renewal in the United States, 1949-1974" 
Joshua L. Rosenbloom, University of Kansas and NBER, Thomas Weiss, University of Kansas and NBER, and Peter C. Mancall, University of Southern California, "Widow's Allowances and the Standard of Living in the Colonies and States of the Middle Atlantic Region Before 1800"

Anne Hanley, Northern Illinois University, "Pests and Pestilence: Public Health in BelleÉpoque Brazil"

\section{ECONOMIC HISTORY SOCIETY ANNUAL CONFERENCE 26-28 MARCH 2010, UNIVERSITY OF DURHAM CALL FOR ACADEMIC PAPERS}

The 2010 annual conference of the Economic History Society will be hosted by the University of Durham from 26 to 28 March. Accommodation and some meetings will be located in Collingwood College and the majority of sessions in two adjacent buildings on the Science Site. The college is a 10-minute walk from the Science Site and shuttle buses will be provided at certain times of the day.

The conference program committee welcomes proposals in all aspects of economic and social history covering a wide range of periods and countries, and particularly welcomes papers of an interdisciplinary nature. Preference may be given to scholars who did not present a paper at the previous year's conference. Those currently studying for, or who have recently completed, a Ph.D. should submit a proposal to the New Researcher session; please contact Maureen Galbraith (ehsocsec@arts.gla.ac.uk) for further information.

The committee invites proposals for individual papers, as well as for entire sessions (three speakers, 1.5 hours duration). The latter should include proposals and synopses for each paper in the session, although the committee reserves the right to determine which papers will be presented in the session if it is accepted. If a session is not accepted, the committee may incorporate one or more of the proposed papers into other panels.

For each proposed paper, please send (preferably by e-mail) a brief c.v. and a short abstract (including name, postal and e-mail addresses) of 400-500 words to: Maureen Galbraith, Dept. of Economic \& Social History, University of Glasgow, Lilybank House, Bute Gardens, Glasgow G12 8RT, Scotland, UK. E-mail: ehsocsec@arts.gla.ac.uk.

For full consideration, proposals must be received by 14 September 2009. Notices of acceptance will be sent to individual paper givers by 16 November 2009 .

Should your paper be accepted, you will be asked to provide the following: An abstract of the paper for inclusion in the conference booklet (by 14 December 2009); a brief nontechnical summary of your paper for the "Media Briefings" section of the society's website (by 1 February 2010); and an electronic copy of your full paper (for the conference website) or a web address where the paper is available for consultation (by 1 March 2010).

It is the normal expectation that speakers who submit a proposal for a paper to the Conference Committee should be able to obtain independent financial support for their travel and conference attendance. However, a very limited support fund exists to assist overseas speakers who are unable to obtain funding from their own institution or from another source. Details of this fund and an application form can be obtained from the society's administrative secretary, Maureen Galbraith (ehsocsec@arts.gla.ac.uk). It is important that a completed application form is included with the paper proposal and the brief c.v. which are submitted to the committee for the September deadline. Only in exceptional circumstances will later applications for support be considered. 